\title{
A "PENNURTH OF ARSENIC FOR RAT POISON": THE ARSENIC ACT, 1851 AND THE PREVENTION OF SECRET POISONING
}

\author{
by
}

PETER BARTRIP *

In this country any chemist or druggist can furnish the means of self-destruction or murder for a few pence, and in too many instances have done so with the utmost indifference. The sale of a poison is regarded as a mere act of commercial intercourse; tant pis for the unfortunate victim of error or passion; he has the benefit of a coroner's inquest; the vendor of the poison receives a reprimand, and things resume their natural course - that is, arsenic and oxalic acid are retailed without compunction, and men are hurried from time to time into eternity. ${ }^{1}$

In July 1845 the Provincial Medical and Surgical Journal, the forerunner of the $B M J$, reported a fatal poisoning. Around 4.00 p.m. on an April afternoon the mother of "a remarkably fine and healthy child"-a twenty month old boy-left a cupboard door open and unattended "for a few seconds". On her return "she was horrified at seeing the child mounted on a step, and eating from a box of paste kept for the purpose of destroying mice". She rushed to her son and, having extracted a large quantity of the paste from his mouth, made him swallow a dose of ipecacuanha wine as an emetic. The boy vomited freely and by $6.00 \mathrm{p} . \mathrm{m}$. appeared to have got over the worst. Later that evening, however, he grew restless and refused food. His extremities and face turned cold, his lips livid; his eyes became sunken, his pupils fixed and dilated. At 11.30 p.m. he died. The paste he had eaten proved to be a mixture of honey, flour, and white arsenic (oxide). ${ }^{2}$

Accounts of accidental poisonings, such as this, were commonplace in the medical and lay press of the 1840s. So too were reports of arsenic being used to procure abortion and commit suicide or murder. Whether the "unusual degree of attention and interest" in arsenic which characterized the decade reflected an increased incidence of poisoning is debatable. Probably the Pharmaceutical Journal was right in ascribing it to recent improvements in chemical detection, the scientific controversy these engendered, and "notorious trials"-including that of Marie Lafarge in France. ${ }^{3}$

* Peter Bartrip, Ph.D., University of Oxford, Centre for Socio-Legal Studies, Wolfson College, Oxford OX2 6UD.

\footnotetext{
1 Provincial Medical Journal and Retrospect of the Medical Sciences, 1842, pp. 35-6.

2 PMSJ, 16 July 1845 , pp. 453-4.

${ }^{3}$ Pharmaceut. J, 1841, i: 277. The Lafarge trial excited huge interest in the United Kingdom, as well as in France, on account of the youth, rank, and beauty of the accused, combined with the enormity of her
} 
Also of importance, perhaps, was the growing interest in vital statistics and public health which marked the early Victorian period. Subsequently, arsenic and crime were kept in the forefront of public attention by some of the most sensational Victorian murder trials, including those of Dr Thomas Smethurst, Madeleine Smith, and Florence Maybrick. ${ }^{4}$

Until 1851 there were no legal restrictions on the sale of arsenic. It, or any other poison, could be bought and sold by anyone. The introduction of controls may be approached from a number of directions. Most simply it represents an example of a paternalistic State, faced with an apparently serious problem of accidental and secret poisoning, rejecting laissez-faire ideology in favour of a sensible policy of intervention aimed at protecting people from themselves and others. But while such an explanation might clarify some dimensions of the Act, it would not reveal how, in its terms and origins, it owed much to the medical and pharmaceutical reform movements. Neither would it show how, in some quarters, the need for regulation was perceived in terms of tackling a social problem which was gender and class specific.

Of course, arsenic was not the only poison responsible for accidental or deliberate loss of human life, but it was possibly the commonest cause of poisoning fatalities, and certainly the most publicized. Arsenic, Robert Christison maintained, "is the poison most frequently chosen for the purpose of committing murder". When Christison wrote his famous Treatise on poisons in 1829 he devoted more space to arsenic than to any other substance. ${ }^{5}$ A metal from which a number of highly toxic compounds could be formed, arsenic, in its various guises, had a vast range of applications. Extensively used in the production of fly-papers and for poisoning rodents, it was also employed in many trades and occupations including farming, medicine, veterinary medicine, taxidermy (as a preservative), and the manufacture of "an amazing array of articles", including many in regular domestic use. Curtains, furniture fabrics, lampshades, ornaments, artificial flowers, carpets, linoleum, childrens' toys, and books were among the products which routinely contained arsenic as a colouring agent. The rooms of innumerable Victorian houses were lined with wallpaper coloured with arsenical dyes; their inhabitants wore clothes dyed with arsenical pigments; at night they lit their premises with candles containing arsenic. The food they ate and the tobacco they smoked was often wrapped in paper tinted with arsenic. So extensive were the uses to

alleged crime. See PMSJ, 1840, p. 17; Joseph Shearing, The lady and the arsenic. The life and death of a Romantic: Marie Capelle, Madame Lafarge, London, Heinemann, 1937; Edith Saunders, The mystery of Marie Lafarge, London, Clerke \& Cockeran, 1951; Colin Wilson, Written in blood. A history of forensic detection, Wellingborough, Equation, 1989, pp. 72-6.

${ }^{4}$ S. W. F. Holloway, Royal Pharmaceutical Society of Great Britain 1841-1891. A political and social history, London, The Pharmaceutical Press, 1991, p. 221; see Harold Eaton, Famous poison trials, London, Collins, 1923; Richard D. Altick, Victorian Studies in Scarlet, London, J. M. Dent \& Sons, 1972, chaps. 7 , 8, 15; Leonard A. Parry (ed.), The trial of Dr. Smethurst, Edinburgh and London, Hodge, 1931; F. Tennyson Jesse (ed.), The trial of Madeleine Smith, Edinburgh and London, Hodge, 1927; H. B. Irving (ed.), The trial of Mrs. Maybrick, Edinburgh and London, Hodge, 1922; Trevor L. Christie, Etched in arsenic, London, Harrap, 1969. There is a vast literature on sensational Victorian poisonings, including at least seven books on the Maybrick case.

${ }^{5}$ Robert Christison, A treatise on poisons, in relation to medical jurisprudence, physiology, and the practice of physic, Edinburgh, Adam Black, 1829. In later editions the section on arsenic was "considerably extended". See Pharmaceut. J., 1845, iv: 384-5; 3 Hansard CXIV (13 March 1851) cols 1300-1; (24 March 1851) cols 422-4. 
which arsenic was put that "it was hard to escape exposure . . in life or in death". It is likely that such constant exposure contributed much to the chronic ill-health of the period. ${ }^{6}$

In agriculture arsenic was used in huge quantities for dipping sheep (4 lb. per 100 sheep was required) and steeping grain-sometimes with serious consequences for farm labourers, stock, and wild game. That arsenic was prescribed as a medicine might occasion surprise, but Hooper's New medical dictionary (1848) notes that "like many other virulent poisons, [it] is a safe and useful medicine when judiciously employed". It "generally agrees very well" with children, wrote Thomas Hunt who regarded it as "potent", "effective", and "safe". Arsenious acid and arsenite of potash were taken internally as tonics, as well as to treat fevers and recurring ailments such as migraine or neuralgia. Applied externally, arsenic was used as an escharotic in the treatment of cancer and skin diseases such as psoriasis. Hunt termed it "the medicine for cutaneous disease". It remained in medical use throughout the nineteenth century. ${ }^{7}$

Because of its many applications and its cheapness, arsenic was readily obtainable from grocers, chemists, and others "under the most frivolous pretences", even by the "lowest of the vulgar". Although not mentioning arsenic by name, William Farr, the statistical head of the General Register Office, surely had it in mind when, in 1840, he referred to "poisons, which can be procured of the most destructive and subtle nature, with extraordinary facility". To illustrate the casual public attitude towards arsenic, a Household Words article recounted an incident in a rural grocer's shop where "a little girl" was observed to order "tea, sugar, soap, currants, red herrings, and flour ... 'and two ounces of arsenic"'. Some country druggists reckoned to sell more than one ton of the poison per year. Because it was colourless, odourless, tasteless, soluble in water, and fatal in small doses, it was easy to administer surreptitiously or ingest in error. "It is generally asked for "to kill rats", , wrote Farr, "but it is questionable whether arsenic kills more rats than human beings". 8

\footnotetext{
${ }^{6}$ PP 1857 (2) XII, Select Committee on the Sale of Poisons. Evidence of A. S. Taylor, pp. 658, 700-1; J. T. Arlidge, The hygiene diseases and mortality of occupations, London, Percival, 1892, pp. 431-8; Thomas Oliver, Diseases of occupation, London, Methuen, 1908, pp. 216-18; Malcolm Morris, 'Arsenic' in Thomas Oliver (ed.), Dangerous trades. The historical, social and legal aspects of industrial occupations as affecting health, by a number of experts, London, John Murray, 1902, pp. 378-81; P. A. B. Raffle, W. R. Lee, R. I. McCallum, and R. Murray (eds), Hunter's Diseases of occupations, London, Hodder \& Stoughton, 1987 ed., pp. 259-63; M. Harper, 'Occupational health aspects of the arsenic extractive industry in Britain (1868-1925)', Br. J. Industr. Med., 1988, 45: 602-5. Numerous articles and books have speculated about the connection between Napoleon's last illness and the arsenical wallpaper present in his house of exile on St Helena. Recent studies include David Jones, 'The singular case of Napoleon's wallpaper', New' Scientist, 1982, 86: 101-4; David E. H. Jones and Ken Ledingham, 'Arsenic in Napoleon's wallpaper', Nature, 1982, 299: $626-7$.

${ }^{7}$ Hooper's New medical dictionary, 8th ed., London, Longman, 1848, p. 180; Thomas Hunt, 'Memoir on the medicinal action of arsenic; collected from the reported experience of the members of the Provincial Medical and Surgical Association, and other sources', Trans. prov. med. surg. Ass., 1849, 16: 383-421; Br. med. J., 1865, i: 299; 1875, i: 571, 634, 741, 747; 1891, ii: 1203-4; Malcolm Morris, 'The history and therapeutic value of arsenic in skin disease', Proc. med. Soc. Lond., 1881, 5: 123-4; John S. Haller Jr., 'Therapeutic mule: the use of arsenic in nineteenth century materia medica', Pharm. in Hist., 1975, 17: 87-100.

${ }^{8}$ PMSJ, 1849, pp. 362-3, 438; 1851, p. 182; Pharmaceut. J., 1841, i: 277; 1847, vi: 539; 1850, ix: 302-3; Christison, op. cit., note 5 above, p. 172; PP 1840 XVII, Second Annual Report of the Registrar-General of
} 


\section{Peter Bartrip}

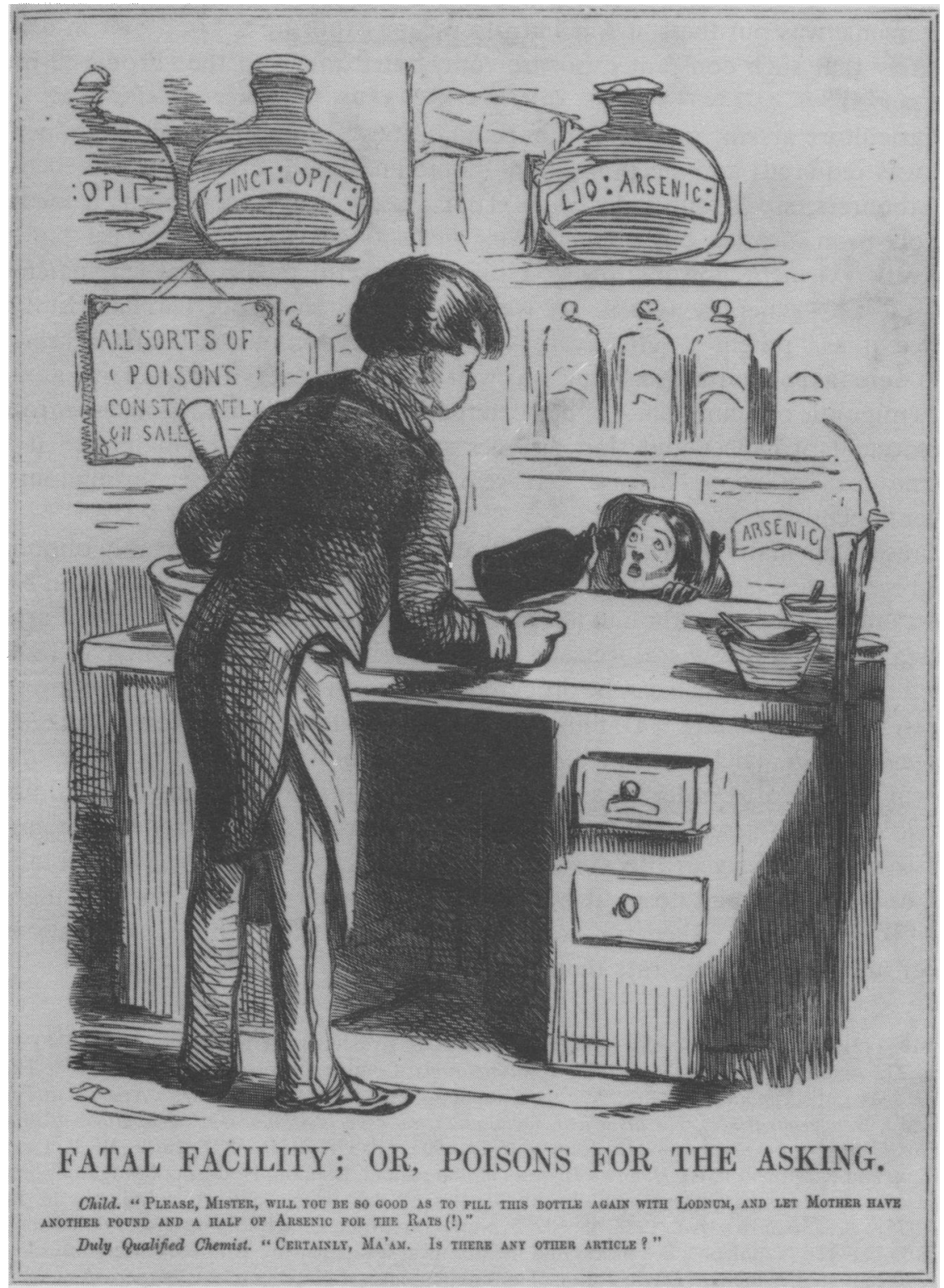

Punch, vol. xvii, 1849, p.97, shelfmark N.2706d, reproduced by permission of the Bodleian Library, Oxford.

For obvious reasons (of diagnosis, concealment, and administrative inconsistency) early Victorian statistics of fatal poisonings have to be treated with scepticism.

Births, Deaths, and Marriages. Letter from William Farr, Appendix, pp. 43-4; PP 1841 (2) VI, Third Annual Report of the Registrar-General . . Appendix, pp. 51-2; PP 1857 (2) XII, Select Committee on the Sale of Poisons, Evidence, p. 582; 'Poison sold here', Household Words, 1850, ii: 155-7, reprinted in The Times, 12 March 1851. 
Systematic statistics for suicide, for example, were compiled only from the late 1850s and these were notoriously unreliable. ${ }^{9}$ For all their defects, however, the extant data are worth examining if only because they show how the incidence of poisoning was being represented to contemporary society. Hence, official statistics for the eleven years 1839-1849, inclusive, suggest that a total of 239 people were tried for murder or attempted murder by poison (substances unspecified) in the United Kingdom. ${ }^{10} \mathrm{~A}$ parliamentary return of 1839 found that during the two years, 1837-38, there occurred, in England and Wales alone, as many as 540 deaths by poisoning of which over one-third (185) involved arsenic. ${ }^{11}$ These latter figures are likely to be incomplete if only because no return was submitted by the Middlesex coroner, Thomas Wakley. According to Farr, some 500-600 people per year, many of whom were children, were "ascertained to die" by poisoning in England alone; about 100 of these were victims of arsenic. Some French statistics suggested that arsenic was used in one out of every two cases of criminal poisoning. In the Pharmaceutical Journal it was even claimed that $90-95$ per cent of French and German poisonings involved arsenic. ${ }^{12}$

Whether all this pointed to arsenic poisoning as a great and growing problem is uncertain. The 1837-38 figures (of 540 fatal poisonings -185 involving arsenic) were regularly quoted by those who favoured regulation as evidence of a crisis of serious proportions. But while Farr was concerned that the incidence of violent death in Britain was greater than anywhere on the Continent, he could show little hard evidence for the existence of an epidemic of deaths from arsenic consumption. In 1841 he produced statistics which showed that of 3,839 violent deaths in selected areas, only 128 were attributable to poisons of which only 15 (less than 12 per cent) could be ascribed to arsenic. Crowther and White are surely correct in their assessment that suicide by poison was rare, homicidal poisoning rarer, and that the main dangers lay in accidental poisoning at home and at work. Yet the movement for arsenic regulation was principally concerned with "secret poisoning", probably because "the secret and premeditated use of poison had a powerful hold on the public imagination". ${ }^{13}$

The reliability of poisoning statistics depended in part on the ability of chemists or medical practitioners to identify the presence of the poison. Christison maintained that there were "few substances in nature, and perhaps hardly any other poison, whose presence can be detected in such minute quantities and with so great certainty"

\footnotetext{
${ }^{9}$ Olive Anderson, Suicide in Victorian and Edwardian England, Oxford, Clarendon Press, 1987, pp. 2, 10-11.

${ }^{10} \mathrm{PP} 1850 \mathrm{XLV}$, Return of the Number of Persons tried in the United Kingdom for Murder and Attempts to Murder by the Administration of Poison, in each Year, 1839 to 1849, inclusive, pp. 447-53.

${ }^{11}$ PP 1839 XXXVIII, Returns from the Coroners of England and Wales, of all Inquisitions held by them during 1837 and 1838, where Death was found by Verdict of Jury to have been caused by Poison, pp. 409-44.

12 PMSJ, 1849, pp. 437-8, 531; Pharmaceut. J., 1844, iv: 108; Alfred S. Taylor, Medical jurisprudence, 4th ed., London, John Churchill, 1852, p. 57; Christison, op. cit., note 5 above, p. 172; PP 1841 (2) VI, Third Annual Report of the Registrar-General ... Appendix, p. 52.

${ }_{13}$ Ibid., pp. 49-51. "Violent death" was defined as being caused by gunshot and other wounds, fractures and contusions, burns, scalds, poisoning, drowning, hanging and strangling, gases, suffocation, and other causes not specified. The selected areas were London, Birmingham, Manchester, Salford, Liverpool, West Derby, the "Mining Districts", and the "agricultural districts of Norfolk and Suffolk"; Anne Crowther and Brenda White, On soul and conscience: the medical expert and crime. 150 years of forensic medicine in Glasgow, Aberdeen University Press, 1988, p. 19.
} 
as arsenic. ${ }^{14}$ But here the great toxicologist was displaying unwonted confidence in the accuracy of chemical analysis. Until the development of the Marsh Test in 1836 "arsenic was recognized, if at all, by the garlic odour on heating with charcoal and by precipitation reactions which were not specific". Even the Marsh Test was far from foolproof. "Ingenious" and "rigorous" it might have been, but in inexperienced hands it could yield contradictory results, as it did in the Lafarge trial. The same was true of the subsequently developed Reinsch Test (which was bungled by the well-known forensic scientist, Alfred Swaine Taylor, in the Smethurst Trial of 1859). Hence, even in 1849, when the PMSJ referred to the availability of "unerring chemical tests" for detecting arsenic, testing was by no means totally accurate. W. H. Wills was perhaps closer to the truth when, a year later, he wrote in Charles Dickens's Household Words of "the practical difficulties of detection" rendering murder "easy". Certainly, problems of applying the Marsh Test were still being discussed in the medical journals in the 1860 s. $^{15}$

Uncertainty of detection was important, for a fully reliable test might have deterred some of those who planned to poison others with arsenic. ${ }^{16}$ In the absence of certainty there was a strong case for restricting the availability of the poison. But such a case existed anyway if accidental poisoning was thought to be widespread. In fact, the first attempt to regulate, in 1819 , did focus upon accidental rather than criminal poisoning. Following a Preamble which referred to frequent "dangerous and fatal" accidents occurring through the consumption of poisons mistaken for medicines, the Bill proposed that certain drugs, including white arsenic and arsenic acid, should not be sold or kept for sale unless labelled "Poison". It went on to specify that certain quantities (presumably small) of arsenic and oxalic acid should be sold only if mixed with, in the case of arsenic, carbon. Clearly this strategy promised to thwart the poisoner as well as preventing accidents. ${ }^{17}$ The Bill was opposed by the Committee of Associated Apothecaries, which believed it was "likely to embarrass the dispensing of medicines, and not calculated to effect the object intended". The committee gained a hearing in the Commons after which the Bill was withdrawn. ${ }^{18}$ The issue then appears to have disappeared from public view for some twenty years. In 1837, however, the Coroner for Dorset, alluding to a suspicious fatality involving arsenic, remarked in an

\footnotetext{
${ }^{14}$ Christison, op. cit., note 5 above, p. 172; see Pharmaceut. J., 1841, i: 278; 1842, i: 512-13.

15 W. A. Campbell, 'Some landmarks in the history of arsenic testing' Chemistry in Britain, 1965, i: 198-202; idem, 'The history of the chemical detection of poisons' Med. Hist., 1981, 25: 202-3; A. G. Mervyn Madge, 'Murders and the detection of arsenic' Pharmaceut. Historian, 1985, 15: 12-14; Wilson, op. cit., note 3 above, pp. 62-4, 69-70, 83; George Fownes, 'On the detection of arsenic in complicated liquids' Pharmaceut. J., 1842, i: 512-13; PMSJ, 1840, p. 17; 1849, p. 438; Br. med. J., 1865, ii: 20; 'Poison sold here', op. cit., note 8 above. On Taylor see Noel G. Coley, 'Alfred Swaine Taylor, MD FRS (1806-1880): forensic toxicologist', Med. Hist., 1991, 35: 409-27. Household Words articles were published anonymously, but authors can be identified owing to the survival of the journal's Contributors' Book. See Anne Lohrli (comp.), Household Words: A Weekly Journal, 1850-1859, Conducted by Charles Dickens, University of Toronto Press, 1973.

16 Pharmaceut. J., 1841, i: 277.

${ }^{17}$ PP 1819 IB, 'A Bill for Establishing Regulations for the Sale of Poisonous Drugs, and for the Better Preventing the Mischiefs arising from the inattention or neglect of Persons vending the same', pp. 943-5.

18 Jacob Bell and Theophilus Redwood, Historical sketch of the progress of pharmacy in Great Britain, London, Pharmaceutical Society, 1880, p. 70.
} 
official return that it "is much to be regretted persons who vend poison are not required to register the day, hour, and to whom sold. For want of a compulsory registration the ends of justice are too frequently defeated". The document in which these remarks appeared also provided ample evidence of numerous accidental poisoning deathsoften as a result of the accidental consumption of arsenic kept as rat poison. ${ }^{19}$

Throughout the 1840s many different proposals were made for restricting the availability of arsenic. In 1841, for example, Farr suggested that suicide by poisoning could be reduced if medicines containing poisons were available only on prescription, if arsenic was no longer supplied for vermin control, and poisons used in industry obtainable only by those holding an employer's certificate. ${ }^{20}$ In 1842 the Provincial Medical and Surgical Journal, reacting to the death of a woman who took a dose of arsenic in mistake for her prescribed medicine, called for the law to compel those who sold poisons to label their products appropriately. ${ }^{21}$ The London Medical Gazette argued for coloured bottles being kept in locked cabinets, with poisons handled by separate staff, operating from separate counters and using separate scales. ${ }^{22}$ Some preferred that arsenic should be sold only when mixed with another substance which gave it a distinctive taste and appearance. A Times leader of 1848, supported restrictions on sales to anyone who could not produce a guarantee from a third person such as a clergyman or medical practitioner. At least two local Acts of Parliament (for Manchester and Stockport) did prohibit sales of arsenic and prussic acid to anyone under the age of 21 and to anyone else except in the presence of two witnesses and provided that various details of the purchase were entered in a poison book. ${ }^{23}$

This debate on restricting the free trade in arsenic had much in common with contemporary discussions about the need for State intervention to control other "intolerable" social conditions. Misuse of arsenic, like child labour in industry, conditions on emigrant ships, and other social "problems", was seemingly giving rise to public anxiety which could be alleviated only by government action aimed at removing the cause of that concern. ${ }^{24}$ It is easy to understand how arsenic was defined as a serious problem in need of legislative intervention. But to see this process simply in terms of a consensual desire for public protection would be to oversimplify, for in the course of the arsenic debate, the question became linked with other issues, notably medical and pharmaceutical reform, which were as much concerned with professional

${ }^{19}$ PP 1839 XXXVIII, Returns from the Coroners of England and Wales, pp. 409-44.

${ }^{20}$ PP 1841 (2) VI, Third Annual Report of the Registrar-General . . Appendix, p. 52. See Anderson, op. cit., note 9 above, p. 362 .

${ }^{21}$ Provincial Medical Journal and Retrospect of the Medical Sciences, 1842, pp. 35-6; see Pharmaceut. J., 1845, iv: $416-17$.

22 Lond. med. Gaz., 1848, vii: 845-8.

${ }^{23}$ The Times, 26 Dec. 1843; 26 Sept. 1844; 14 Jan. 1845; 17 Jan. 1845; 11 Sept. 1845; 21 Aug. 1847; 18 Oct. 1847; 1 Nov. 1847; 5 Sept. 1848; 20 Oct. 1848; 15 Nov. 1848; 1 May 1849; 10 Aug. 1849; 14 Aug. 1849; Lancet, 30 March 1850, p. 400; 4 May 1850, p. 552; Pharmaceut. J., 1846, v: 535; 1850, ix: 352; Holloway, op. cit., note 4 above, p. 221.

${ }^{24}$ Oliver MacDonagh's classic and controversial article describing this process, and how it gave rise to a "nineteenth century revolution in government" generated a long-running historical debate. Oliver MacDonagh, 'The nineteenth century revolution in government', Historical J., 1959, i: 52-67. See the same author's A pattern of government growth, 1800-1860: the Passenger Acts and their enforcement, London, Macgibbon \& Key, 1961. 


\section{Peter Bartrip}

as with public protection. It would not be going too far to say that the organized medical and pharmaceutical professions "hijacked" the arsenic issue, skilfully exciting and exploiting public anxieties about accidental and intentional poisoning, for their own purposes. ${ }^{25}$

The story of the medical reform movement's protracted struggle for an autonomous, self-regulating, licensed, and registered medical profession free from competition from quacks has been frequently told. ${ }^{26}$ At the time professional lobbyists tended to argue the case for reform largely in terms of the importance of safeguarding the public from the incompetent. Today, medical historians tend to place more emphasis on power struggles within the profession and on organized practitioners' objective of achieving "professional closure". From its foundation by Jacob Bell in 1841, the Pharmaceutical Society was, like its counterparts in medicine, such as the Provincial Medical and Surgical Association (British Medical Association from 1856), with which it shared many features, concerned with uniting chemists and druggists in one profession, raising their status and income, and acquiring a monopoly of practice for its members. It saw the principal means of realizing these goals as being to restrict by law entry to the profession to those in possession of the appropriate qualifications and licences, to establish a system of professional education, examination, registration, and government, and to preserve certain matters for the exclusive exercise of professional expertise. ${ }^{27}$

The connection between the need for professional regulation and control of the sale of poisons was repeatedly made in the Pharmaceutical Journal. ${ }^{28}$ In 1848 , for example, the President of the Pharmaceutical Society, addressing the society's annual meeting, said:

When, gentlemen, I think how important a position is held by the Chemist, of how useful a member of society he is designed to be, I turn with sorrow to look upon those with whom the name is in many parts of the country associated. At present, as the law stands, any man, however ignorant - an individual unable even to sign his own name-half of whose shop is stored with butter, bacon, cheese, or tape, shall from the other half have the power of dispensing, to any person applying, preparations of mercury, arsenic, opium etc. etc. ${ }^{29}$

He went on to point out that in France, Germany, Russia, Prussia and elsewhere, examinations had to be passed and certificates obtained before an individual could dispense and vend drugs. ${ }^{30}$ In conclusion, he called for government legislation to

\footnotetext{
${ }^{25}$ This linkage has been brilliantly explored in connection with opiate regulation in Virginia Berridge and Griffith Edwards, Opium and the people. Opiate use in nineteenth century England, New Haven and London, Yale University Press, 1987.

${ }^{26}$ See, for example, Ivan Waddington, The medical profession in the Industrial Revolution, Dublin, Gill \& Macmillan, 1984, and Irvine Loudon, Medical reform and the general practitioner 1750-1850, Oxford, Clarendon Press, 1987.

27 Pharmaceut. J., 1843, ii: 741; 1849, viii: 557-8; Holloway, op. cit., note 4 above. See Berridge and Edwards, op. cit., note 25 above, especially pp. 113-16.

${ }^{28}$ See, e.g., Pharmaceut. J., 1845, iv: 347.

29 Ibid., 1848, vii: 561 .

${ }^{30}$ On overseas practice on the sale of poisons see PP 1852 XIII, select Committee on the Pharmacy Bill, Evidence, pp. 351, 354, 357, 365-6; PMSJ, 1849, pp. 362-3; Lancet, 1848, p. 193.
} 
protect the public and the medical profession (whose prescriptions might be erroneously dispensed). The clear implication was that accidental poisoning would be minimised not by use of coloured bottles, accurate labelling, locked poison cabinets and the like, but by the establishment of a qualified and licensed profession with a monopoly over the sale of drugs and poisons. The point was made explicitly later that year in an anonymous article in the Pharmaceutical Journal. This argued that the best means of guarding against "poisoning by ignorance" was the passing of an Act of Parliament regulating the qualifications of chemists and druggists. ${ }^{31}$

As interested as the Pharmaceutical Society was in the sale of poisons, the main thrust for legislative controls came not from it but from the youthful Provincial Medical and Surgical Association. In June 1849, a Torquay practitioner, Jonathan Toogood, prompted by the recent Freeman poisoning case, in which a Bridgwater woman was tried, convicted, and executed for the murder of four members of her family, raised the subject in letter published in the PMSJ. Concerned by what he claimed was an epidemic of secret poisoning, he had already persuaded the Town Council of Bridgwater to petition Parliament and lobby ministers for controls on the sale of poisons. He himself had written to Sir George Grey and submitted a petition to the Commons. Since these efforts had all come to nothing, Toogood wanted the PMSA to take up the matter, restricting itself to the problem of arsenic, "the agent usually employed to effect this diabolical purpose" (of secret poisoning), and especially its "indiscriminate sale . . to illiterate persons". "I cannot help thinking", Toogood wrote, "that a petition to Parliament from so numerous and influential a body as [the PMSA] . . . would rouse the public mind, and command that attention which an humble individual can hardly expect". 32

As a result of Toogood's letter the question of secret poisoning was placed on the agenda of the Association's 1849 annual meeting. Toogood was unable to attend, but those present agreed that "the practice of secret poisoning ... had prevailed of late years to a most fearful extent". A committee was appointed to petition the House of Commons for restrictions on the "indiscriminate sale of poisons". For the strategic reason that "it is better to destroy one prominent enemy, than to weaken our forces by attempting to combat many", the petition mentioned arsenic alone. It proposed that all retailers of arsenic should be licensed; that it should be mandatory that small quantities of arsenic were sold only if mixed with a material which could be easily detected if added to food; that all purchasers of arsenic should be accompanied by a witness; and that vendors should keep a book recording all sales along with the names and addresses of both the purchaser and his witness. All but one of these proposals (that dealing with adulteration) had been suggested by Toogood. In October 1849 the Association's Arsenic Committee entered into discussions with representatives of the Pharmaceutical Society. Meanwhile, the PMSA's General Council unsuccessfully sought an audience with the Home Secretary. ${ }^{33}$

31 Pharmaceut. J., 1848, vii: 260-3; see 1850, ix: 352-3.

32 PMSJ, 1849, pp. 362-3; Pharmaceut. J., 1851, x: 482.

33 PMSJ, 1849, pp. 438, 467-8; Pharmaceut. J., 1849, ix: 249; James Tunstall, Observations upon the sale of arsenic and the prevention of secret poisoning, London, Simpkin, Marshall \& Co, 1849, p. 12. 


\section{Peter Bartrip}

What was the PMSA's motivation in taking up the arsenic question; was it self-interest, altruism, or a combination of both? First, arsenic, because of its medicinal applications, was a legitimate topic of concern for medical practitioners. Its misuse could be said to bring them into disrepute by association, particularly since poisoning could produce symptoms which might be easily misdiagnosed. Restrictions on the availability and use of arsenic were bound to affect medical interests. Second, such evidence as was available appeared to indicate that arsenic poisoning was a serious problem from which the public was in need of protection. Here was the opportunity for the Association to render a valuable public service. Third, the arsenic question provided the Association with a "stick" with which it could beat the unqualified chemists and druggists engaging in "over the counter" practice and prescribing. If they could be portrayed as irresponsible, their businesses might suffer, thereby benefiting the medical practitioners to whom many of the public would be likely to turn. Finally, the Association would have the chance to enhance its reputation for honourable and responsible behaviour. During the protracted and ongoing struggle for medical reform, a disunited and quarrelsome profession appeared to be intent on pursuing selfish aims. On the one hand there was the objective of securing a monopoly of practice for duly qualified practitioners, and, on the other, a power struggle within the profession as rank and file practitioners challenged the privileges of the medical corporations. By taking up a public interest question the PMSA could claim that it, at least, was interested in more than narrow, sectional, goals. This promised to raise its standing, boost recruitment to its ranks, advance its claims to represent all practitioners, and promote medical reform by displaying the profession to the public, MPs, and the government in an appealing light. As James Tunstall said, by taking up the cause of arsenic regulation the PMSA would convince "those who question the utility of our own annual congresses, that we meet not only for our benefit and advantage, but for the advancement of the dearest interests of humanity". 34

At first the Pharmaceutical Journal was sceptical that the PMSA's proposals could work. ${ }^{35}$ But its editor, the Pharmaceutical Society's president and founder, Jacob Bell, soon realized that resolution of the arsenic question might do much to advance pharmacists' professional goals:

It must be evident to all that something ought to be done, since, in the present state of the law, every person calling himself a Chemist and Druggist might sell every kind of poison to any person applying for it. Poisons were also sold by grocers, oilmen, and hucksters, especially in the country. Some advantage might result from the restriction of the sale of these dangerous substances to medical men and Chemists and Druggists; but in order to make the law effectual, it would be necessary to introduce another law, defining who is a Chemist and Druggist, and providing for the education and examination of those who assume that name. By carrying out this provision, for which object chiefly the Pharmaceutical Society was founded, more benefit would be conferred on the public than by an imperfect plan relating to any particular poison. ${ }^{36}$

${ }^{34}$ PMSJ, 1849, p. 467.

35 Pharmaceut. J., 1849, ix: 160-1.

${ }^{36}$ Ibid., 1849, ix: 206. 
In the existing circumstances there was little point in restricting the sale of arsenic to chemists for, as a committee of the Pharmaceutical Society realized,

it is perfectly obvious that until the term Chemist and Druggist is defined by Act of Parliament, and associated with a compulsory examination, the proposed restriction [on the sale of arsenic] would be inoperative. It would in fact be worse than useless, since any person desiring to sell poison might write Chemist and Druggist over his door, introduce the coloured bottles into his window and enjoy the privilege. ${ }^{37}$

Hence, the arsenic question offered the Pharmaceutical Society the prospect of accelerating the progress of pharmaceutical reform. The organization of the profession was the Society's overriding concern. Even after it had committed itself to seeking an Arsenic Act, its Journal noted that pharmaceutical chemists

are unable to comprehend the policy, or appreciate the consistency, of the Minister, who proposes to bring in a bill for regulating the sale of a few poisons as a means of protecting the public health, and neglects to avail himself of the opportunity of regulating by law the qualifications of those who deal in poisons of every description. ${ }^{38}$

The PMSA and the Pharmaceutical Society were natural allies. Both were keen to polish their public and professional "images"; both wished to strike a blow against the unqualified chemists and druggists who were taking away their business and barring the way to higher status and respectability.

Anxious to gain the support of Pharmaceutical Society members, James Tunstall, a leading PMSA advocate of poisons regulation, stressed that the support of the pharmaceutical chemists for the PMSA's ideas "would be conducive ... to their own advancement, by promoting the improved system of education which they had for some years been engaged in introducing". It is, indeed, no coincidence that the Arsenic Act, 1851 was speedily followed by the introduction of the Pharmaceutical Society-inspired Pharmacy Bill, 1852, the original (though unrealized) aim of which was to exclude the unqualified and unregistered from exercising the business of chemist. $^{39}$

In November 1849 the PMSA's Arsenic Committee combined with the Pharmaceutical Society's committee. Immediately, the latter body issued a questionnaire on the sale of poisons to all members of the Society. This sought information on such matters as the nature and scale of the arsenic trade, the incidence of accidental poisoning, and opinions on the desirability of regulation. The way in which the information obtained was presented in the Pharmaceutical Journal precludes the possibility of anything beyond the most simple statistical analysis. A total of 1,600 questionnaires were distributed to which 993 replies were received,

${ }^{37}$ Ibid., 1850, ix: 356.

${ }^{38}$ Ibid., $1850, \mathbf{x}: 56$.

${ }^{39}$ Ibid., 1849, ix: 208; PP 1852 IV, Bill for Regulating the Qualifications of Pharmaceutical Chemists, pp. 73-82. For earlier versions of the Bill see PP $1851 \mathrm{~V}$, pp. 321-38; Berridge and Edwards, op. cit., note 25 above, p. 114; Holloway, op. cit., note 4 above, chap. 4 . 


\section{Peter Bartrip}

though not all respondents appear to have answered all the questions. Of the 761 who admitted selling arsenic, "almost all" reported that they already took precautions in terms of inquiring the purpose for which the poison was required, the identity of the purchaser, "and not infrequently" insisting on registering the sale in the presence of witnesses. To the question: "Would the prohibition of the retail sale of arsenic be in your opinion desirable?", affirmative replies outnumbered the negative in a ratio of $2: 1$, thereby endorsing Tunstall's belief that many chemists saw regulation as offering "relief from an onerous responsibility". 40

After analysing the results of the questionnaire the Pharmaceutical Society's committee decided that "the requirements of legitimate trade" were inconsistent with a total prohibition on the sale of arsenic. At the same time, it believed that regular chemists and druggists generally behaved responsibly when selling poisons and that few accidents occurred from items they sold. It concluded, unsurprisingly, that the "unrestricted sale of poisons... by unqualified persons, is the great source of danger". The problem was, as the Pharmaceutical Journal recognized, that if chemists and druggists acquired a retail monopoly over poisons then, in the absence of legislation legally defining membership of those professions, grocers and others who already sold poisons would simply rename themselves in order to retain their privilege. This would be precisely the reverse of what the Pharmaceutical Society wanted. For this reason it refused to contemplate general regulation of poisons until after the attainment of pharmaceutical reform. But it was prepared to support a Bill dealing with arsenic in the hope that its success would "lead to a further consideration of the more comprehensive measure relating to the qualifications of those who practice Pharmacy". 41

Together, the PMSA and the Society came up with three reform suggestions; these differed somewhat from those included in the Association's earlier petition. They were that retail sales of arsenic should be confined to chemists, druggists, and apothecaries; that only adult males (either in person or on their written instructions) should be eligible purchasers; that a poison book should record the date and purpose for which the arsenic was required, the signature of the applicant and a witness, one of whom had to be known to the vendor (a handwritten order would be acceptable provided the vendor could identify the writing and pasted the order in the poison book). ${ }^{42}$

The PMSA presented a memorial to the Home Office calling for reform. The Council of the Pharmaceutical Society did likewise, though in its communication "attention was especially drawn to the fact that no legislative enactment, in regard to the sale of poisons, could be complete and effectual, unless accompanied with a provision for regulating the qualifications of Pharmaceutical Chemists". In May 1850 , when responding to a suggestion in the Commons that a select committee should investigate the poisons question, Sir George Grey, the Home Secretary, stated that a government Bill had already been prepared. ${ }^{43}$

40 Pharmaceut. J., 1849, ix: 207, 253-4; 1850, ix: 302-3, 352-8.

41 Ibid., pp. 451-2, 558.

42 Ibid., 1849, ix: 201, 205-10, 249-50; 1850, ix: 451-2, 557-8.

43 Ibid., p. 558; 1850, x: 56; 3 Hansard CX (1 May 1850), cols 1056-8. 
Although the Pharmaceutical Journal claimed that the Bill, which was not actually published till March 1851, reflected PMSA/Pharmaceutical Society proposals, only one of their suggestions was included in it. This was for the particulars of each sale of arsenic - except where it formed part of a medical prescription-to be entered into a poison book. For each transaction it was proposed that the following details would be recorded: quantity sold, purpose for which required, date of sale, name and address of purchaser, status of purchaser (i.e., householder or lodger). ${ }^{44}$

The Arsenic Bill received its first reading in March 1851 following a short debate in the House of Lords. Thereafter it quickly completed its passage through Parliament, with minimal discussion, gaining the Royal Assent on 5 June. Attenuated debate was, in fact, deliberate government policy. As the Chancellor of the Duchy of Lancaster (the Earl of Carlisle) said when introducing the measure, poisoning fascinated "certain kinds of mind" and it was not intended to put ideas into the heads of the suggestible. The original Bill aimed to check secret (rather than accidental) poisoning without interfering with the legitimate trade in arsenic. It was limited to one poison alone partly because arsenic poisoning was considered to be particularly prevalent and partly because while it was feasible to "debar the ignorant" from using arsenic, it was less easy to prevent the knowledgeable from using alternatives. If arsenic was perceived to be the poison of the working classes, as this observation seems to imply, then the Arsenic Bill proposed to regulate their purchases while leaving those of their social and economic superiors largely unfettered. ${ }^{45}$

Although Lord Carlisle appears to have had little faith that arsenic regulation would achieve the desired effect, admitting, in the course of debate that "the evil [of secret poisoning] . . . could only be successfully combatted by teaching our people the true spirit of Christianity", the Bill negotiated its first two stages through the Lords. While it was in Committee, however, Carlisle received a "vast number of communications" suggesting amendments. ${ }^{46}$ In particular, he came under strong pressure from the PMSA and the Pharmaceutical Society. They argued that the Bill would be "quite inoperative for the purposes intended, viz., the prevention of accidents and offences by the use of arsenic". As a result of their representations Carlisle amended his Bill in several ways, the effect of which was to make the final measure in many respects similar to the PMSA/Pharmaceutical Society proposals. Purchasers as well as vendors would be obliged to sign the poison register; if unknown to the vendor they would be unable to make their purchase except in the presence of a witness who knew both parties to the transaction, such witness also being required to sign the register; for sales of quantities less than $10 \mathrm{lb}$. arsenic would have to be mixed with soot or indigo unless the purchaser stated that this would render it useless for his purposes; sales would be restricted to those of full age though not, as Carlisle, the PMSA, and the Pharmaceutical Society would have preferred, to men only, the decision to discriminate against women being dropped "owing to the indignant remonstrances of ladies". For the PMSA (though not the Pharmaceutical Society) the one important exclusion from the amended Bill was a clause restricting arsenic

${ }^{44}$ PP 1851 VI (Lords), Sale of Arsenic Regulation Bill, pp. 303-6.

453 Hansard CXIV (13 March 1851) cols 1300-1; CX (1 May 1850) cols 1056-8.

46 PMSJ, 1851, pp. 181-4, 470-1; 3 Hansard CXV (24 March 1851) cols 422-4. 


\section{Peter Bartrip}

transactions to the medical and pharmaceutical professions. Carlisle rejected this idea, presumably because, in the current state of the law, there was no legal definition of a pharmacist or medical practitioner. His amended Bill received its third reading in the Lords on 24 March $1851 .^{47}$

With the Bill due to be transferred to the Commons the PMSA and Pharmaceutical Society increased the pressure for its acceptance with the addition of some further controls. Tunstall sent a copy of his 1849 pamphlet, Observations upon the sale of arsenic and the prevention of secret poisoning, to every Member of Parliament. He also urged all members of the Association to lobby their MPs. Three members of the Joint Arsenic Committee, assisted by George Hastings, the barrister son of the PMSA's founder, drew up a clause providing for the prosecution of anyone whose careless handling of arsenic led to the death of another. ${ }^{48}$ However, when the Arsenic Bill came before the Commons it was not debated on any of its three readings, receiving the Royal Assent in a form unchanged from when it left the House of Lords. It remained open, therefore, for grocers and others to sell the poison, but not without registering each sale and observing the additional statutory requirements. In other respects, however, the PMSA's Council was "much pleased . . . that a Bill, principally founded on the petition presented by this Association" had become law. "It will be admitted", it stated in its annual report, "that this is an enactment in the right direction, and whatever may be the defects of the law, it cannot fail to produce good results", 49

How good, then, were the results? Following the passage of the Act the PMSJ was quick to publicize the conviction and punishment (with a $£ 5$ fine) of an Accrington druggist who sold uncoloured arsenic to a minor. But while Bell and Redwood maintain that arsenic fell "out of fashion" as the criminal's poison of choice, there are no means of gauging the extent of compliance with the law or the number of convictions for breaching it. In 1857 Alfred Taylor stated that he had never heard of a penalty under an Act which he believed to be "much violated". Even so, at this stage, he too was prepared to say that the Arsenic Act had done "some good". Others, however, believed it had merely led potential poisoners and suicides to select alternative substances. ${ }^{50}$

Criminal poisoning by arsenic did not become a thing of the past after 1851 . Indeed, within a few years of the passing of the Act there occurred two causes célèbres involving arsenic: the "slow poisoning case at Burdon", near Darlington, in 1855, and, two years later, the Madeleine Smith trial. When, some twelve years after the passing of the Act, Alfred Taylor investigated the "dangers arising to the Public Health in the conditions under which drugs and poisons are retailed", he was far less sanguine than he had been in 1857, reporting that the Arsenic Act was "a dead letter, so far as the public safety is concerned". The poison's

${ }^{47}$ PMSJ, 1851, pp. 181, 471; 3 Hansard CXv (24 March 1851) cols 422-4; Pharmaceut. J., 1851, x: 484.

48 PMSJ, 1851, pp. 182, 471.

49 An Act to Regulate the Sale of Arsenic, 14 \& 15 Vict. c. 13; PMSJ, 1851, p. 456.

50 PMSJ, 1851, pp. 587, 616; Bell and Redwood, op. cit., note 18 above, p. 245; PP 1857 (2) XII, Select Committee on the Sale of Poisons Bill, Evidence, pp. 564, 612, 656, 669. 


\section{The Arsenic Act 1851}

great cheapness (one penny to twopence an ounce) places it within the reach of the poorest persons. It is sold to any applicant on the most frivolous pretences ... The better class of druggists do not sell arsenic by retail; the grocer, chandler, oilman, and village shopkeeper are the principal vendors of this poison; and it is clear from the numerous deaths which take place from white arsenic that they set the law at defiance, and sell the poison in an uncoloured state $\ldots . .51$

Notwithstanding the presence of the 1851 Act on the Statute Book:

The trade in poisons in this country may be considered to be as open and free as it possibly can be. I doubt whether by any Act of Parliament, greater facilities for the purchase of poison for criminal purposes could be given. No one wishing to destroy another by poison and having the knowledge to make a selection among drugs, can meet with any difficulty in carrying out his design ....52

Likewise, in 1879, the Sanitary Record could refer to "the present system of free trade in arsenic". 53 The conclusion would seem to be that the Arsenic Act might as well never have been passed.

In any case, the Act tackled only the counter trade in pure arsenic; commercial users were unaffected by the legislation. Accidents and chronic illness were, therefore, bound to continue - as, indeed, they did. Thus, in 1857, at an industrial school in Norwood, Surrey, 340 children were poisoned by arsenic as a result of drinking milk diluted with water drawn from a boiler, the boiler containing an arsenic solution introduced on the previous night for the purpose of removing calcareous deposits. ${ }^{54}$ In Bradford, in 1858, some 200 people were poisoned, 20 fatally, when arsenic found its way into a batch of peppermints owing to the mistake of a druggist's assistant who supplied a confectioner with a cask of arsenic instead of sulphate of lime (plaster of Paris) - itself an adulterant. Similar cases occurred subsequently, though usually on a smaller scale. In 1874, 60 Cornish miners were wilfully poisoned when a quantity of arsenic was placed in a water tank. Most dramatically, in 1900, beer drinkers, especially in Lancashire and Staffordshire, fell ill in their thousands in consequence of what was eventually proved to be an outbreak of chronic arsenic poisoning. In this case the poison had found its way into sugars used in the brewing process owing to the use of impure sulphuric acid at the refining stage. As late as 1943, 150 people fell ill, 2 of whom died, after eating sausages contaminated with arsenic. These, of course, were the sensational cases. It should not be forgotten that an unknown degree of chronic arsenic poisoning occurred as the result of exposure to the wide range of arsenically coloured products in regular domestic use. ${ }^{55}$

${ }^{51}$ PP 1864 XXVIII, Sixth Report of the Medical Officer to the Privy Council, Appendix 16, p. 759.

52 Ibid., p. 760.

53 Sanitary Rec., 1879, x: 4; see also The Times, 7 March 1872.

54 Sixth Report, op. cit., note 51 above, p. 767.

55 Ibid., p. 765; Sanitary Rec., 1875, ii: 42; The Times, 7 December 1874; Br. med. J., 1900, ii: 1492-3, 1769-71; PP 1901 IX, Report to the Local Government Board on the Recent Epidemic Arsenical Poisoning Attributed to Beer, by Dr. G. S. Buchanan, pp. 255-81; PP 1901 IX, Royal Commission Appointed to Inquire into Arsenical Poisoning from Consumption of Beer and other Articles of Food or Drink, First Report, pp. 283-98; Campbell, 'Some landmarks', op. cit., note 15 above, 202; David Wright, 'Arsenic at St Andrews, 1943' Med. Hist., 1983, 27: 184-5; M. P. Earles, 'A history of the Society', Pharmaceut. J., Supplement, 27 April 1991, s. 8. 


\section{Peter Bartrip}

Given the limited terms of the Arsenic Act and the absence of effective enforcement provisions there is little reason to suppose that it exerted a significant influence upon the overall incidence of poisoning. The suggestion that the unlawful use of arsenic was "controlled" by the Act is misleading. Rather, as Holloway suggests, it "was more a declaration of intent than an effective piece of legislation". 56

At first sight the origins and passage of the Arsenic Act, 1851 may appear to be of little more than antiquarian interest. But, as the first-ever restriction on sale of poisons in the United Kingdom, the Act is undeserving of the neglect to which historians have subjected it. In the 1840s it was occasionally suggested that legislative restrictions on the sale of poisons "would not suit the prejudices and notions of freedom prevalent in Great Britain". 57 But not only did the Act dent the laissez-faire ideology which prevailed in medicine and pharmacy, it established a precedent for later restrictions on opiate and poison sales, and on food, drink, and drug adulteration. The principle of caveat emptor received its first setback in the Arsenic Act.

The Act was also a factor in medical reform, not least in helping the PMSA, whose influence was ultimately vital, to establish its credibility and legitimacy. Until now the Arsenic Act has been mainly linked with the question of pharmaceutical reform, but in reality it owed more to PMSA than to Pharmaceutical Society lobbying. If the law was to make exceptions in favour of medical practitioners, as it did by excluding prescribed arsenic from the terms of the Act, it was necessary that such practitioners should be duly educated, qualified, and registered. This implied the need for medical reform. Certainly the Act was also a first legislative step towards pharmaceutical reform. ${ }^{58}$ Indeed, it presaged the Pharmacy Act of 1852 and the much more important Pharmacy and Poisons Act, 1868. The 1868 Act, by confining the sale of a range of poisons to qualified pharmacists, encouraged the Pharmaceutical Society to prosecute unqualified vendors in order to defend its members' professional and commercial interests. In so doing it supplied the enforcement which had been largely absent under the terms and operation of the 1851 Act.

Holloway expresses surprise that Bell did not stress poisons control as a justification for his 1852 Pharmacy Bill. ${ }^{59}$ The fact is, however, that ventilation of the arsenic question had rendered this unnecessary by achieving what the Pharmaceutical Society had failed to bring about over the preceding decade, that is, placing pharmaceutical reform on the legislative agenda. This was acknowledged in the Pharmaceutical Journal as early as 1850 when an article observed that

discussion on the sale of poisons has had a good effect. It has led irresistibly to the consideration of the subject of Pharmacy, and this has produced a conviction that the two questions, Pharmacy and Poisons, are far more intimately connected than Medical and Pharmaceutical reform. This is a step in advance, and we trust it will lead to a favourable result. ${ }^{60}$

${ }^{56}$ Berridge and Edwards, op. cit., note 25 above, p. 80; Holloway, op. cit., note 4 above, pp. 221, 227.

57 Pharmaceut. J., 1845, iv: 342.

${ }_{58}$ Bell and Redwood, op. cit., note 18 above, p. 203.

${ }^{59}$ Holloway, op. cit., note 4 above, p. 180.

60 Pharmaceut. J., 1850, x: 56. 
With the passage of the Arsenic Act the close association between poisons and pharmaceutical regulation was established. The Pharmaceutical Society, having helped to bring the 1851 Act into being, opposed further poisons regulation except as a means of realizing its professional goal of reserving pharmaceutical practice for qualified pharmacists. Hence, in the late 1850s, it successfully opposed the series of Bills which followed an apparent epidemic of criminal poisoning in 1855-56. ${ }^{61}$ Because the Society refused to comtemplate general regulation of poisons except as part of a "package" involving pharmaceutical reform, pharmacy legislation and sale of poisons regulation became irrevocably linked. After 1851 any government which wished to introduce further controls on the sale of poisons had to do so by way of the Pharmacy Acts.

61 Bell and Redwood, op. cit., note 18 above, pp. 242-9, 253-6, 262-6, 278-9, 320; PP 1857 VI (Lords). pp. 297-318; PP 1857-8 IV, pp. 335-41; PP 1859 (i) II, pp. 729-40. 